\title{
KEPEMIMPINAN BERBASIS KECERDASAN EMOSI PADA KETUA MAJELIS TAKLIM KHOIRUN NISA' SURABAYA
}

\author{
Tri Djoyo Budiono \\ STID Al-Hadid, Surabaya \\ djoyobudi@gmail.com
}

\begin{abstract}
Abstrak: Studi dilakukan pada ketua Majelis Taklim Khoirun Nisa' karena dipandang berhasil mendirikan dan mengembangkan organisasi pengajian ibu-ibu kampung di Wonokusumo Surabaya. Karakter ekonomi warganya menengah ke bawah dan cenderung emosional, membuat tidak mudah dan ada tantangan tersendiri untuk mendirikan dan mengembangkan pengajian di lokasi tersebut. Studi ini bertujuan memaparkan kepemimpinan berbasis kecerdasan emosi pada ketua Majelis Taklim ketika mendirikan dan menjalankan kepemimpinan. Melalui metode kualitatif deskriptif, sumber data diperoleh dari wawancara. Teori yang digunakan adalah kepemimpinan berbasis kecerdasan emosi rumusan Daniel Goleman, Richard Boyatzis, dan Annie McKee. Hasil studi menunjukkan bahwa ketua Majelis Taklim Khoirun Nisa' memiliki kompetensi kepemimpinan berbasis kecerdaan emosi dalam bentuk kemampuan kesadaran diri (self awareness) dan pengendalian diri (self management) yang dibuktikan dengan kesadaran dan pengendalian perasaan khawatir saat mendirikan pengajian ibu-ibu, kesadaran dan pengendalian perasaan marah saat mendapatkan pernyataan yang menyudutkan dari anggota pengajian, kesadaran dan pengendalian perasaan marah saat ada yang menggunjing masalah makanan. Kemampuan sesadaran sosial (social awareness) dibuktikan saat merasakan keadaan masyarakat dan anggotanya. Kemampuan pengelolaan relasi (relationship management) yang dibuktikan saat subjek mengelola relasi sosial dengan memecahkan masalah pembelian seragam, memecahkan masalah adanya orang yang menggunjing masalah makanan, sehingga organisasi berjalan dengan baik.

Kata kunci: kepemimpinan, kepemimpinan berbasis kecerdasan emosi, Majelis Taklim Khoirun Nisa'.
\end{abstract}

\begin{abstract}
The study is conducted to the chief of Majelis Taklim (Islamic Forum) Khoirun Nisa' Surabaya since she is considered successful in establishing and developing Al-Quran reciting organization of kampong women in Wonokusumo Surabaya. Its residents are from middle and lower-economic class. They tend to be emotional. These social characteristics make difficult and challenging to establish and develop Al-Qur'an reciting organization in this area. This study aims to describe emotional intelligence based leadership of the chief of Majelis Taklim (Islamic forum) when she establish and lead the forum. Through descriptive qualitative method, data source was taken from interviewing. A theory applied is emotional intelligence bsed leadership formulated by Daniel Goleman, Richard Boyatzis and Annie McKee. The result of study shows that the chief of Majelis Taklim Khoirun Nisa' owns competence of leadership based on emotional intelligence under the forms of the abilities of self awareness and self management proven with consciousness and management of
\end{abstract}


anxiety when she established the forum, consciousness and management of anger when she got dissented statement from member of forum and when members of forum told slanderous gossip about food. The ability of social awareness was proven when she felt the social and member's conditions. The ability of relationship management was proven when subject managed social relationship by solving problems of purchasing uniform and gossips on food so that the organization keeps running well.

Key words: leadership, emotional intelligence based leadership, Majelis Taklim Khoirun Nisa'.

\section{Pendahuluan}

Dalam setiap kerja bersama apalagi dalam suatu lingkup organisasi dakwah dibutuhkan pemimpin untuk mengefektifkan dan mengefisienkan setiap langkah dan kegiatan tersebut. ${ }^{1}$ Pemimpin merupakan faktor penentu dalam meraih sukses bagi sebuah organisasi dakwah sebab pemimpin yang sukses dan mampu mengelola organisasi, dapat memengaruhi orang lain secara konstruktif, dan mampu menunjukkan jalan serta tindakan benar yang harus dilakukan secara bersama-sama. ${ }^{2}$ Tugas seorang pemimpin dalam arti kepemimpinan dalam organisasi dakwah merupakan tugas yang sangat besar dan mulia, dan tugas ini tidak dapat dipikul oleh semua orang, karena selain tugasnya yang berat, juga tanggung jawab menggerakkan dan memengaruhi orang lain secara sukarela. Adanya tanggung jawab dunia dan akhirat, itulah salah satu masalah yang tidak semua orang mampu melakukannya. $^{3}$

\footnotetext{
1 Munir dan Wahyu Ilahi, Manajemen Dakwah, (Jakarta: Kencana, 2009), 211-212.

2 Maslina Daulay, "Kepemimpinan dalam Manajemen Dakwah," Jurnal Hikmah, Vol. VI, 48 No. 02 Juli 2012, 48.

3 Mahmuddin, "Kepemimpinan Dakwah," Jurnal Dakwah Tabligh, Vol. 15, No. 2, (Desember 2014): 186.
}

Sondang P. Siagian menegaskan bahwa seorang pimpinan tidak seyogianya hanya mampu berperan selaku atasan yang keinginan dan kemauannya harus diikuti oleh orang lain yang berperilaku seperti seorang bos. ${ }^{4}$ Untuk itulah seorang pemimpin, terlebih pemimpin organisasi dakwah dalam menghadapi perkembangan yang semakin pesat itu, memerlukan suatu sikap yang tepat pula yaitu pengambilan keputusan yang cepat dan tepat. ${ }^{5}$ Dengan sikap yang tepat, maka hal ini akan berdampak pada pencapaian tujuan organisasi secara efektif dan efisien.

Agar dapat memberikan sikap yang tepat, seorang pemimpin perlu memiliki kemampuan, salah satunya adalah kecerdasan emosional. Menurut Daniel Goleman, kecerdasan emosi seorang pemimpin dapat menginspirasi hingga menjadikan bawahannya tetap termotivasi dan memiliki komitmen terhadap organisasi. Pemimpin yang tidak memiliki kecerdasan emosi bahkan dapat mengganggu suasana emosi di organisasi. ${ }^{6}$ Seorang pemimpin

\footnotetext{
${ }^{4}$ Sondang P. Siagian, Organisasi, Kepemimpinan dan Perilaku Administrasi, (Jakarta: Gunung Agung, 1986), 20.

5 Ibnu Syamsi, Pengambilan Keputusan dan Sistem Informasi, (Jakarta: Bumi Aksara, 1995), 1.

6 Daniel Goleman et al, Primal Leadership Kepemimpinan Berdasarkan Kecerdasan Emosi, terj. Susi Purwoko (Jakarta: PT Gramedia Pustaka Utama, 2006), $x$.
} 
melakukan penyikapan terhadap anggota tanpa mempertimbangkan aspek emosional yang terjadi, hal ini akan membuat suasana menjadi tidak nyaman dan kurang produktif, contohnya seorang pemimpin organisasi dakwah yang memarahi anggotanya karena kesalahan yang dilakukan, tanpa melihat kondisi emosi anggotanya, kemudian berdampak pada anggota tersebut tidak mau lagi membantu organisasi dakwah tersebut. Tidak semua pemimpin memiliki kecerdasan emosi untuk memengaruhi emosi secara positif dari bawahannya, tidak semua pimpinan mampu memberikan motivasi kepada anggotanya serta membangun semangat antusiasme terhadap anggotanya. ${ }^{7}$

Salah satu hal yang menarik untuk dikaji tentang kepemimpinan yang berbasiskan pada kecerdasan emosi adalah kepemimpinan pada majelis taklim ibu-ibu. Majelis taklim ibu-ibu yang salah satunya dalam bentuk pengajian keliling rutin mingguan, mempunyai fungsi sosial untuk mempererat hubungan antar warga, selain itu secara ekonomis adanya konsumsi bagi ibu pengajian, dan secara motivasi beragama dapat memberikan semangat kepada anggotanya untuk mengkaji agama, serta menambah pengetahuan keagamaan warga sekitar. ${ }^{8} \mathrm{Di}$ dalamnya dibutuhkan kecerdasan emosi yang tinggi dalam

\footnotetext{
${ }^{7}$ lbid., 8-9.

${ }^{8}$ Afnani Jayadina, "Fungsi Sosial Pengajian Bergilir di Rumah Warga (Studi tentang Pengajian Bergilir dan Upaya Memakmurkan Masjid di Dusun Pugeran, Jambidan, Banguntapan, Bantul, Yogyakarta)," (Skripsi, Universitas Islam Negeri Sunan Kalijaga, Yogyakarta, 2016), 72-73.

${ }^{9}$ AP, Wawancara oleh Penulis, 25 September 2018. 10 "Polisi Tangkap 9 Penjudi di Makam Wonkid," pojokpitu.com, diunduh pada tanggal 19 Mei 2016, http//www.PojokPitu.com. ; "Pejudi 'Tiarap', Pagupon Dibakar," Surya.co, diunduh pada tanggal 19 Mei
}

mengelolanya. Sebab dalam pengajian ibuibu yang menjadi anggota dan pengurusnya adalah para wanita yang mempunyai kecenderungan emosional, kurang bisa menahan emosi, dan kesibukan yang tinggi, apalagi majelis taklim ibu-ibu yang berasal dari kelas ekonomi menengah ke bawah dan secara pendidikan kurang, maka tingkat emosionalnya juga kurang terkontrol.

Berdasarkan hasil wawancara dengan salah seorang warga Wonokusumo Kidul menjelaskan bahwa, ibu-ibu Wonokusumo Kidul cenderung emosional, contohnya pertengkaran ibu-ibu yang disebabkan oleh masalah tulisan di facebook, yang kemudian berdampak pada perang mulut, sampai pada pertengkaran fisik (jambakjambakan). ${ }^{9}$ Selain itu dulunya terdapat permasalahan di antaranya perjudian, seperti judi burung dara yang menjadi aktivitas harian, atau judi ketika ada acara hajatan warga $^{10}$ juga pernah terjadi pembunuhan antar tetangga yang mengakibatkan seorang ibu meninggal dunia dibunuh oleh tetangga laki-laki. Hal tersebut berawal dari konflik masalah hutang antar tetangga kemudian menjadi perang mulut, dan berakhir dengan pembunuhan. ${ }^{11}$ Dengan kondisi masyarakat yang secara pengendalian emosi sangat kurang, mudah marah, mudah meluapkan emosi dalam bentuk pertengkaran bahkan

2016, http//www.surya.co.id. ; "Judi undangan Wonokusumo Digerebek Polisi," Lensalndonesia.com, diunduh pada tanggal 19 Mei 2016, http//www.Lensalndonesia.com.

11 "Hutang 14 Juta Wanita Paruh Baya Dibunuh Dengan Sadis," Surabayanews.net, diunduh pada tanggal 19 Mei 2016, pukul 16:06 http//www.surabayanews.net. ; "Pelaku Pembunuhan di TPI Romo Kalisari Tertangkap," detiknes.com, diunduh pada tanggal 19 Mei 2016, http//www.detiknews.com. 
sampai fisik berujung pembunuhan seperti itu, maka membangun dan memimpin majelis taklim ibu-ibu di Wonokusumo Kidul bukanlah suatu hal yang mudah, diperlukan kecerdasan emosi yang baik terutama dari pemimpinnya.

Daniel Goleman, Richard Boyatzis, dan Annie McKee mengungkapkan bahwa seorang pemimpin yang memiliki kecerdasan emosi dapat diukur dari beberapa aspek, yakni aspek pertama yaitu kompetensi pribadi yang terdiri dari self awareness, self management, dan aspek yang kedua kompetensi sosial yang terdiri dari social awareness, dan relationship management. Self awareness merupakan kemampuan seseorang menyadari keadaan dirinya sebagai landasan dalam bersikap. Self management merupakan kemampuan seseorang dalam mengendalikan emosi dirinya. Social awareness merupakan kemampuan dapat merasakan apa yang dirasakan oleh orang lain. Sedangkan relationship management merupakan kemampuan dalam membangun kerjasama dan menyelesaikan konflik. $^{12}$ Kecerdasan emosi diindikasi dimiliki oleh pemimpin organisasi Majelis Taklim Khoirun Nisa' yang sekaligus sebagai pendiri, contohnya saat ada persoalan anggota yang menggunjing masalah makanan yang disajikan waktu pengajian, ada yang membandingbandingkan, ada yang menyatakan enak, kemudian digunjingkan di belakang. Saat mendengar hal tersebut, Ketua Majelis Taklim Khoirun Nisa' awalnya ingin marah sebab masalah makanan saja kenapa sampai dipermasalahkan, akan tetapi beliau tidak sampai meluapkannya, dan mencoba untuk meredam kemarahannya tersebut. Dalam

12 Goleman., et al, Primal Leadership., 44-45. proses menenangkan diri, Ketua menyadari kalau sampai kemarahan ini langsung diluapkan akan berdampak tidak baik. Beliau mencoba memahami kenapa orang-orang menggunjing masalah makanan, kemudian ditemukan sebabnya karena belum menghayati tujuan dari pengajian, dan belum memahami dampak menggunjing terhadap hubungan sosial. Oleh karenanya setelah pengajian, Ketua menyampaikan kepada anggotanya tentang tujuan dari pengajian. Berikut kutipan pernyataannya, "bahwa tujuannya adalah lillaahita'ala, niat mengaji mencari ilmu, berharap pahala dari Allah, bukan berharap mendapatkan makanan yang enak. kalau mendapatkan makanan apapun itu, mari diterima dengan ikhlas sebagai berkah dari Allah, jangan dirasani enak gak enaknya, sebab kalau dirasani masalah makanannya yang tidak enak, maka akan menyinggung perasaan orang lain, akhirnya mengakibatkan permusuhan, prasangka yang tidak baik, dan bisa jadi anggota yang tersinggung akan keluar dari pengajian karena masalah makanan. Jangan sampai hal yang awalnya baik, malah jadi buruk." 13 Setelah diberikan masukan tersebut, beliau menjelaskan bahwa ibu-ibu tidak menggunjing kembali masalah makanan.

Dari contoh tersebut, menunjukkan indikasi bahwa Ketua Majelis Taklim Khoirun Nisa' mempunyai kemampuan self awareness yang dibuktikan dengan kemampuan sebagai pemimpin dalam membaca keadaan atau emosi diri saat mendengar orang yang menggunjingkan masalah sajian makanan saat pengajian, beliau menyadari bahwa dirinya dalam keadaan marah, akan tetapi mencoba mengendalikan dirinya.

\footnotetext{
${ }^{13}$ Ibu K, Wawancara oleh Penulis, 24 September 2018.
} 
Kemampuan self management ini terlihat saat pemimpin mencoba mengendalikan emosi marahnya dengan menghayati dampak kalau kemarahannya diluapkan justru tidak baik. Selanjutnya mencoba mendalami sebab orang-orang menggunjing masalah makanan sampai menemukan akar masalahnya. Kemampuan social awareness terlihat dari kepeduliannya sebagai pemimpin untuk memecahkan masalah ini dengan memberikan masukan terhadap anggota pengajian Majelis Taklim Khoirun Nisa' akan tujuan pengajian yang sebenarnya dan memberikan penyadaran akan dampak menggunjing sekaligus mengajak tidak melakukan hal itu lagi. Sedangkan kemampuan relationship management terlihat dari kemampuan sebagai seorang pemimpin dalam memecahkan masalah menggunjing tentang makanan tersebut, sehingga dengan tidak adanya lagi orang yang menggunjingkan masalah makanan saat pengajian, maka konflik sosial yang bisa jadi muncul dari masalah tersebut bisa teratasi dan pengajian dapat berjalan dengan lancar.

Dengan kondisi tersebut, studi ini mendeskripsikan kepemimpinan berbasis kecerdasan emosi Ketua Majelis Taklim Khoirun Nisa' Wonokusumo Kidul Surabaya pada tahun 2015-2018 atau sejak proses awal pendirian, menjalanankan kepemimpinan hingga pada tahun 2018. Beberapa manfaat yang didapatkan antara lain, pertama, dapat memberi rekomendasi perilaku kepemimpinan bagi para pemimpin

14 Yudi Asmara Harianto, "Kepemimpinan Rasulullah SAW pada Peristiwa Hudaibiyah Pendekatan Kepemimpinan Emotional Quotient (EQ)," Jurnal Kajian \& Pengembangan Manajemen Dakwah, Vol. 05, No. 2, (Desember, 2015), 1.

15 Rizki Karyanto, "Primal Leadership Khalifah Umar bin Abdul Aziz", Jurnal Kajian \& Pengembangan organisasi dakwah khususnya yang berupa Majelis Taklim ibu-ibu. Sehingga ketika diterapkan, dapat meningkatkan pengaruh emosi positif, hubungan kerja yang harmonis, dan produktif antara pimpinan dengan yang dipimpinnya. Kedua, dapat memberi rekomendasi perilaku kepemimpinan bagi manajer dengan visi tertentu, yang ingin merintis organisasi dakwah berupa majelis taklim, khususnya untuk ibu-ibu dalam kondisi minim sumberdaya dan belum mapannya proses atau sistem manajamen di dalam organisasi yang bersangkutan.

Beberapa penelitian terdahulu yang membahas tentang kepemimpinan berbasis kecerdasan emosi antara lain yang pertama, penelitian yang dilakukan oleh Yudi Asmara Harianto dalam Jurnal Kajian \& Pengembangan Manajemen Dakwah, dengan judul "Kepemimpinan Rasulullah SAW pada Peristiwa Hudaibiyah Pendekatan Kepemimpinan Emotional Quotient (EQ)," Studi ini memiliki fokus pada primal leadership pada Rasulullah saw. ketika terjadi perjanjian Hudaibiyah. ${ }^{14}$ Kedua, penelitian Rizki Karyanto yang berjudul "Primal Leadership Khalifah Umar bin Abdul Aziz" yang juga ditulis pada Jurnal Kajian \& Pengembangan Manajemen Dakwah. ${ }^{15}$ Ketiga, penelitian yang ditulis dengan subjek penelitian yang berbeda, juga oleh Rizki Karyanto, "Kepemimpinan Berbasis Kecerdasan Emosi (Studi Pada Komunitas Pelajar Tanpa Pacaran dan Remaja Masjid Ar-Rahman Surabaya)" ${ }^{16}$ Keempat,

Manajemen Dakwah, vol. 07, No. 01, (Juni 2017 halaman 241-258.

16 Riski Karyanto, Kepemimpinan Berbasis Kecerdasan Emosi (Studi Pada Komunitas Pelajar Tanpa Pacaran dan Remaja Masjid Ar-Rahman Surabaya), (Tesis, Universitas Islam Negeri Surabaya, 2018). 
penelitian yang dilakukan oleh Sarifuddin tentang "Kepemimpinan Kepala Sekolah Berbasis Kecerdasan Emosional di SMA Negeri 1 Soppeng Riaja Kabupaten Baru. ${ }^{\text {"17 }}$ Dari beberapa penelitian di atas kesamaannya adalah membahas tentang kepemimpinan berdasarkan kecerdasan emosi, perbedaannya belum ada penelitian yang membahas tentang kepemimpinan berbasis kecerdasan emosi pada organisasi nonformal seperti kelompok pengajian ibuibu. Dilihat dari subjek penelitiannya, berdasarkan penelurusan, belum ada yang meneliti tentang Majelis Taklim Khoirun Nisa' Wonokusumo Kidul Surabaya. Sehingga dari kajian penelitian terdahulu, membuktikan bahwa penelitian ini belum pernah diteliti sebelumnya.
Studi ini adalah hasil penelitian kualitatif deskriptif. Lokasi penelitian berada di wilayah Wonokusumo Kidul, RT.02 RW.06, Kelurahan Pegirian, Kecamatan Semampir, Surabaya. Subjek yang diteliti adalah Ketua Majelis Taklim Khorun Nisa' sedangkan objeknya adalah perilaku kepemimpinannya. Sumber data yang digunakan terdiri atas empat kategori narasumber, yaitu dari Pendiri dan Ketua Majelis (MT) Khoirun Nisa', pengurus dan anggota Majelis Taklim Khoirun Nisa', pengurus kampung dan warga muslim di sekitar wilayah Wonokusumo Kidul. Berikut tabel daftar narasumber studi ini:

Tabel 1 - Daftar Informan

\begin{tabular}{|c|c|c|c|}
\hline No & Kategori & Informan & Relevansi \\
\hline 1 & $\begin{array}{l}\text { Pendiri \& } \\
\text { Majelis } \quad \text { Taklim } \\
\text { Khoirun Nisa' }\end{array}$ & Ibu K & $\begin{array}{l}\text { Informan adalah pendiri sekaligus Ketua Majelis Taklim } \\
\text { Khoirun Nisa' Wonokusumo Kidul, sehingga menjadi subjek } \\
\text { dalam studi ini. }\end{array}$ \\
\hline 2 & $\begin{array}{l}\text { Birokrasi } \\
\text { Kampung }\end{array}$ & Bapak A & $\begin{array}{l}\text { Data dari Ketua RW terkait untuk mengetahui keadaan } \\
\text { warga Wonokusumo Kidul, serta mengetahui pengaruh } \\
\text { Majelis Taklim Khoirun Nisa' terhadap warga Wonokusumo } \\
\text { Kidul }\end{array}$ \\
\hline 3 & $\begin{array}{lr}\text { Pengurus } & \text { dan } \\
\text { anggota } & \text { Majelis } \\
\text { Taklim } & \text { Khoirun } \\
\text { Nisa' } & \end{array}$ & $\begin{array}{l}\text { a. Ibu Kh } \\
\text { b. Ibu Y } \\
\text { c. Ibu R }\end{array}$ & $\begin{array}{l}\text { Dari pengurus dan anggota Majelis Taklim Khoirun Nisa' } \\
\text { akan dapat diketahui pendapat mereka tentang pola } \\
\text { kepemimpinan Ketua Majelis Taklim Khoirun Nisa' } \\
\text { Wonokusumo Kidul. }\end{array}$ \\
\hline 4 & Warga & $\begin{array}{l}\text { d. Ibu Re } \\
\text { e. AP }\end{array}$ & $\begin{array}{l}\text { Warga menjadi informan terkait fenomena keadaan warga } \\
\text { Wonokusumo Kidul, serta pengaruh kberadaan Majelis } \\
\text { Taklim Khoirun Nisa' terhadap ibu-ibu di sekitar } \\
\text { Wonokusumo Kidul. }\end{array}$ \\
\hline
\end{tabular}

Teknik pengumpulan data dilakukan dengan: (a) wawancara mendalam terhadap para informan di atas, untuk menggali data- data terkait kepemimpinan dalam Majelis Taklim Khoirun Nisa'; (b) observasi, berupa pengamatan langsung terhadap

17 Sarifuddin, Kepemimpinan Kepala Sekolah Berbasis Kecerdasan Emosional di SMA Negeri 1 Soppeng Riaja Kabupaten Barru, (Tesis, IAIN Walisongo, 2010). 
kepemimpinan yang dijalankan. Teknik analisis data yang digunakan menggunakan model Miles dan Huberman, yaitu mulai reduksi data atau pemilahan data, penyajian data dan penarikan kesimpulan, ${ }^{18}$ yang dipandu dengan konsep kepemimpinan berdasarkan kecerdasan emosi.

\section{Kepemimpinan Kecerdasan Emosi pada Organisasi Dakwah}

Kepemimpinan berasal dari kata bahasa Inggris leadership. Kepemimpinan berbeda arti dengan pimpinan. Pimpinan adalah orang yang tugasnya memimpin sehingga pimpinan dapat juga disebut manajer, sedang kepemimpinan adalah sifat atau karakter yang seharusnya dimiliki oleh setiap pemimpin/manajer. ${ }^{19}$ Kepemimpinan adalah kegiatan untuk memengaruhi perilaku orang lain, atau seni memengaruhi perilaku manusia baik perorangan maupun kelompok. ${ }^{20} \quad$ Kepemimpinan menurut Hemphill dan Coons adalah perilaku individu yang mengarahkan aktivitas kelompok untuk mencapai sasaran bersama. ${ }^{21}$ Joseph C. Rost mendefinisikan kepemimpinan sebagai hubungan yang saling memengaruhi antara pemimpin dan bawahan yang menginginkan perubahan nyata yang mencerminkan tujuan bersama. ${ }^{22}$ Dalam konteks organisasi dakwah kepemimpinan organisasi dakwah adalah aktivitas seorang pemimpin organisasi dakwah yang mampu

18 Ismail Nawawi, Metode Penelitian Kualitatif, (Jakarta: Dwiputra Pustaka, 2012), 256-259.

19 Alex S. Nitisemito, Manajemen: Suatu Dasar dan Pengantar, (Jakarta: Ghalia Indonesia, 1989), 140.

20 Thoha Miftah, Kepemimpinan dalam Manajemen: Suatu Pendekatan Perilaku, Cet. IV; (Jakarta: Raja Grafindo Persada, 1993), 4.

${ }^{21}$ Gary Yukl, Kepemimpinan Dalam Organisasi, terj. Budi Supriyanto (Jakarta: Indeks, 2005), 4. memengaruhi anggotanya agar dapat meraih tujuan dakwah bersama-sama dalam wadah organisasi dakwah. Untuk mendapatkan sosok pemimpin yang sesuai, maka seorang pemimpin harus memiliki kriteria antara lain dapat memecahkan masalah yang ada, memiliki kemampuan intelektual yang diakui oleh bawahan atau masyarakat, serta kharisma untuk melakukan perubahan-perubahan di dalam organisasi. ${ }^{23} \mathrm{Hal}$ ini karena dinamika pekerjaan pemimpin senantiasa dihadapkan dengan peluang dan resiko yang memengaruhi organisasi, dan akan berpengaruh pada penentuan pembagian wewenang di dalam organisasi tersebut. ${ }^{24}$

Penelitian ini mengambil fokus pada penelitian kepemimpinan berbasis kecerdasan emosi, sebab seorang pemimpin apalagi pemimpin organisasi dakwah dalam menghadapi perkembangan yang semakin pesat itu, memerlukan suatu sikap yang tepat pula yaitu pengambilan keputusan yang cepat dan tepat. ${ }^{25}$ Dengan sikap yang tepat, maka hal ini akan berdampak pada pencapaian tujuan organisasi secara efektif dan efisien. Untuk dapat mengambil keputusan dengan tepat, seorang pemimpin membutuhkan tidak hanya kecerdasan intelektual saja, akan tetapi juga membutuhkan kecerdasan emosi. Kecerdasan emosi adalah penggunaan emosi secara cerdas atau memanfaatkan emosi tersebut sebagai pemandu perilaku,

22 Triantoro Safaria, Kepemimpinan (Yogyakarta: Graha IImu, 2004), 3.

${ }^{23}$ Veithzal Rivai \& Arviyan Arifin, Islamic Leadership: Membangun Superleadership Melalui Kecerdasan Spiritual (Jakarta: Bumi Aksara, 2009), 8.

${ }^{24}$ Kristin Helstad \& Jorunn Moller, "Leadership as Relational Work: Risks and Opportunities", International Journal Leadership in Education, Vol. 16, No. 3 (2014), 1.

25 Syamsi, Pengambilan Keputusan., 1. 
sehingga hasil perilaku seseorang dapat meningkat. ${ }^{26}$ Pemimpin yang memiliki kecerdasan emosi akan dapat memanfaatkan emosinya sebagai pemandu perilaku, sehingga dapat membangun perilaku kepemimpinan yang efektif, dan dapat membangun pengaruh emosi positif terhadap organisasi dan bawahannya.

Dalam salah satu artikel Journal of Management, Business, and Administration mengungkapkan bahwa aspek kecerdasan emosi (emotional quotient [EQ]) menjadi aspek yang dapat memprediksi secara lebih baik terhadap kinerja kepemimpinan dibandingkan dengan kepemimpinan tradisional yang berpijak pada kecerdasan intelektual (IQ) semata. ${ }^{27}$ Daniel Goleman menjelaskan bahwa kepemimpinan berbasis kecerdasan emosi atau primal leadership merupakan model kepemimpinan yang dibuat atas dasar kaitannya dengan neurologi (otak). Konsep kepemimpinan ini memaparkan bahwa kecerdasan emosi seorang pemimpin dapat menginspirasi hingga menjadikan bawahannya tetap termotivasi menjalankan tugas dan memiliki komitmen terhadap organisasi. Pemimpin yang tidak memiliki kecerdasan emosi bahkan dapat mengganggu keadaan emosi bawahan di tempat kerja. ${ }^{28}$

Kepemimpinan berbasis kecerdasan emosi mengungkapkan konsep bahwa emosi yang dinampakkan pemimpin sangat berpengaruh pada para bawahan karena pemimpin menjadi pusat perhatian, sebagai orang yang paling didengar pendapatnya dan ditiru perilakunya dalam suatu

\footnotetext{
${ }^{26}$ Hendrie Weisinger, Emotional Intelligence at Work, terj. Roro Ratih Ambarwati (Jakarta: Buana IImu Populer, 2006), xv.

27 Fred C. Lunenburg, "Emotional Intelligence in the Workplace: Application to Leadership," International
}

organisasi atau masyarakat. Sekalipun diam, pemimpin akan diamati lebih dari orangorang lain dalam suatu organisasi. Ketika anggota bertanya kepada pemimpin, maka jawaban pemimpin yang akan dijadikan sebagai respon atau landasan perilaku yang paling sah. Oleh karena itu diam atau geraknya pemimpin sangat memengaruhi respon dari para bawahan. Tidak semua pemimpin memiliki kecerdasan emosi untuk memengaruhi emosi dari bawahannya. Ketika pemimpin tidak memiliki kredibilitas dalam hal pengelolahan emosi tersebut, maka bawahan dapat mencari bimbingan emosi kepada orang yang dianggap mampu. ${ }^{29}$

Apalagi dalam konteks organisasi dakwah, seorang pemimpin dalam organisasi dakwah harus dapat menggerakkan anggotanya dengan nilai-nilai dan keteladanan, sebab anggota yang ada di dalam organisasi dakwah bukanlah orang yang digaji, mereka bergerak bukan berdasarkan insentif berupa materi, akan tetapi motivasi bergerak orangorang yang ada dalam organisasi dakwah adalah motivasi nilai-nilai, berupa pahala, rahmat Allah, mendapatkan surga dan dijauhkan dari neraka, kebermaknaan sebagai manusia membantu orang lain, motivasi selanjutnya yang membuat bergerak adalah adanya keteladanan dari pemimpin organisasi dakwahnya, dimana pemimpin organisasi dakwah ini tentunya orang yang mempunyai kecerdasan emosi. Goleman, Boyatzis, dan McKee mengungkapkan bahwa seorang pemimpin yang memiliki kecerdasan emosi dapat diukur dari beberapa aspek, yaitu kompetensi pribadi

Journal of Management, Business, And Administration, 6.

28 Goleman et al, Primal Leadership., $\mathrm{x}$

29 Ibid., 8-9. 
yang terdiri dari self awareness, self management, dan kompetensi sosial yang terdiri dari social awareness, dan relationship management. ${ }^{30}$

Pertama, kemampuan kesadaran diri seorang pemimpin (self awareness). Seorang pemimpin yang mempunyai kesadaran diri (self awareness) dapat digambarkan dengan keadaan diri yang mampu mengenali perasaan-perasaan mereka, dan mengenali bagaimana perasaan memengaruhi diri dan kinerja mereka di dalam organisasi. Pemimpin yang sadar diri-emosional bisa tegas dan otentik, mampu berbicara terbuka tentang emosinya atau dengan keyakinan tentang visi yang membimbingnya. Pemimpin yang memiliki kesadaran diri (self awareness) mempunyai kemampuan penilaian diri yang akurat, mereka dapat menilai diri mereka dengan tepat, seperti mengenali secara mendalam apa-apa saja yang menjadi kekurangan dan kelebihan yang terdapat dalam dirinya. Dengan mengenali kekekurangan dirinya, maka dia tahu apa yang harus dilakukan, kapan harus meminta tolong kepada orang lain. dengan mengetahui kelebihan diri, dia tahu apa yang harus dilakukan untuk mengoptimalkannya, dari sinilah muncul kepercayaan diri yang merupakan keyakinan akan kemampuan diri. $^{31}$ Dalam konteks organisasi dakwah, pemimpin yang mempunyai kemampuan self awareness diketahui dari kemampuannya dalam memahami perasaan-perasaan yang mereka alami ketika memimpin organisasi dakwah, misalnya saat diri merasa sedih karena adanya tekanan dakwah, seorang pemimpin organisasi memahami perasaan sedihnya

30 Ibid., 44-45.

31 lbid., 303-304. tersebut, kemudian dapat memahami apa penyebab perasaan sedihnya tersebut.

Kedua, kemampuan pengelolaan diri pemimpin (self management). Kemampuan ini dapat dilihat dari kesanggupan pemimpin dalam mengelola emosi dirinya, tetap tenang dalam situasi yang sulit sekalipun. Pengelolaan emosi tidak selalu dapat diartikan menekan emosi yang muncul, melainkan memahami emosi yang terjadi dalam diri untuk kemudian dapat mengambil pilihan tindakan yang paling baik untuk dilaksanakan. ${ }^{32}$ Kalau dalam konteks organisasi dakwah, seorang pemimpin yang mempunyai kemampuan dalam mengelola emosi, tidak akan mudah dikendalikan emosinya ketika bertindak, bahkan dirinyalah yang mengendalikan emosinya. Contohnya saat dirundung kesedihan karena adanya tekanan dakwah, seorang pemimpin organisasi dakwah yang mempunyai kemampuan self management selain bisa membaca emosi dirinya dan penyebab emosi dirinya, dapat juga mengendalikan emosi kesedihannya tersebut, mengenali penyebab kesedihan, melakukan pemaknaan positif terhadap tekanan masalah dakwah yang membuat dirinya sedih, sehingga tidak larut dalam kesedihan, tidak putus asa dalam berdakwah karena kesedihan yang diakibatkan tekanan dakwah, tapi malah menjadikan ujian tersebut sebagai semangat dan bangkit untuk berdakwah kembali.

Ketiga, kemampuan kesadaran sosial (social awareness). Pemimpin yang memiliki kompetensi ini dapat merasakan seperti yang dirasakan orang lain, sehingga bisa

\footnotetext{
32 Hendrie Weisinger, Emotional Intelligence at Work, terj. Roro Ratih Ambarwati (Jakarta: Buana IImu Populer, 2006), 37.
} 
membangun hubungan yang baik dengan orang-orang dari berbagai latar belakang. Karena adanya kesadaran sosial terutama dalam berorganisasi, pemimpin dengan kompetensi ini bahkan mampu mengetahui kebutuhan hingga mampu menyediakan dirinya ketika diperlukan oleh bawahannya atau pelanggan dari organisasinya. ${ }^{33}$ Pemimpin yang memiliki kesadaran sosial khususnya dalam konteks organisasi dakwah, akan mampu menyadari keadaan sosial mitra dakwah (mad'uw) yang ada disekitarnya, mempunyai kepekaan emosi terhadap keadaan obyek dakwah (mad'uw), sehingga muncul kepedulian sosial berupa tindakan yang dilakukan pemimpin sebagai subyek dakwah (dai), tindakan pemimpin senantiasa bisa memberikan manfaat bagi lingkungan karena sesuai dengan kebutuhan lingkungannya.

Keempat, kemampuan pengelolaan relasi (relationship management). Pemimpin dengan kompetensi ini mampu mengelola bawahan dengan baik salah satunya mampu menggerakkan orang atau bawahan dalam menggapai visi dan misi organisasi. Maksudnya, pemimpin dengan kompetensi ini tidak hanya sekedar memerintah bawahan untuk mencapai visi misi organisasi, melainkan dia sendiri juga menunjukkan perilaku dan kesungguhan untuk mencapai visi-misi tersebut dalam kehidupan berorganisasi. Hal ini kemudian mampu menginspirasi bawahan untuk mengikutinya. Pemimpin yang memiliki pengelolaan relasi yang baik dengan bawahan, tidak hanya sekedar mempekerjakan bawahan, melainkan juga mampu mengembangkan potensi bawahannya. Dia bisa membuat bawahannya mampu melaksanakan pekerjaan di dalam organisasinya. Ketika terjadi konflik di dalam organisasi, kemampuan pengelolaan relasi ini diwujudkan dengan mengembalikan lagi hubungan relasi yang baik di dalam organisasi. Misalnya ketika ada pertengkaran antarsesama bawahan, maka pemimpin ini mampu meredam atau menyelesaikannya, hingga membangun hubungan dan semangat kerjasama yang baik di dalam organisasinya. ${ }^{34}$

Dalam konteks organisasi dakwah, pemimpin yang memiliki kemampuan pengelolaan relasi (relationship management) mampu membangun hubungan yang baik antara dirinya sebagai pemimpin dengan anggota, juga hubungan yang baik antar anggota organisasi dakwah, serta hubungan yang baik antara anggota organisasi dakwah dengan orang yang di luar organisasi dakwah. Pemimpin organisasi dakwah yang baik, tidak akan memerintah, akan tetapi mengajak anggota untuk bergerak kearah visi misi, sebab anggota bukanlah seorang bawahan yang digaji oleh atasan, sehingga mereka butuh ajakan bukan perintah seperti bos, mereka butuh keteladanan pemimpin, selanjutnya ketika terjadi konflik dalam organisasi dakwah, pemimpin yang mempunyai kemampuan pengelolaan relasi (relationship management) mampu menyelesaikan konflik tersebut dan menjaga hubungan antar anggota organisasi dakwah sehingga bisa berjalan dengan harmonis serta mencapai tujuan organisasi dakwah bersama-sama.

Dari empat aspek kepemimpinan berdasarkan kecerdasan emosi yang telah

\footnotetext{
33 Goleman et.al., Primal Leadership., 305-306.
}

34 Ibid., 306-307. 
dijelaskan di atas, maka dapat digambarkan

dalam bentuk sketsa seperti dibawah ini:

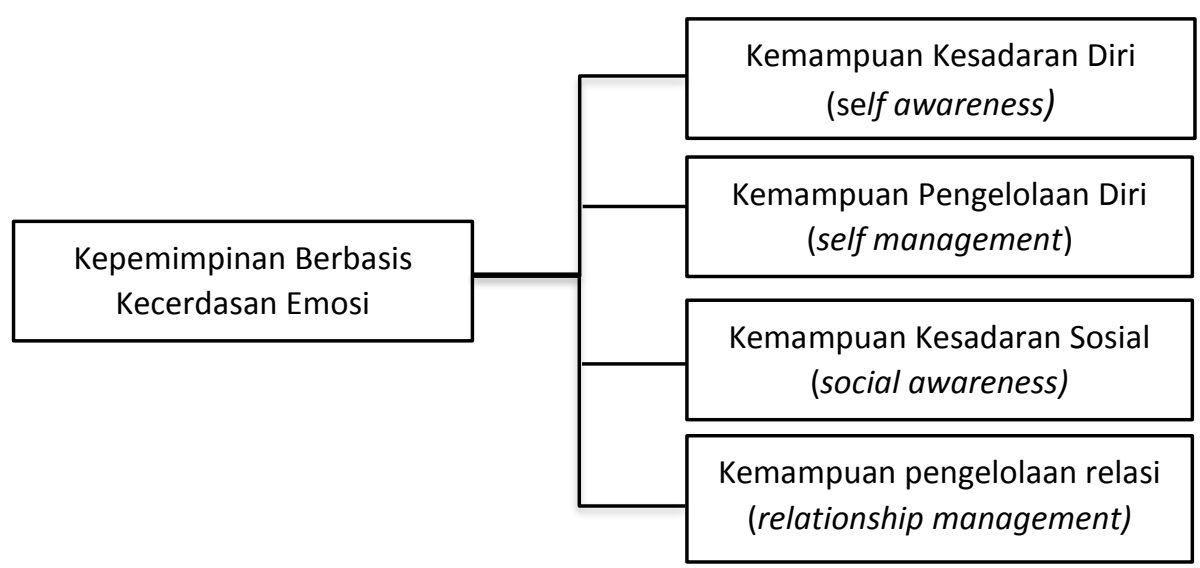

Gambar 1 -Sketsa Empat Aspek Kepemimpinan Berbasis Kecerdasan Emosi

\section{Majelis Taklim Khoirun Nisa' Wonokusumo Kidul Surabaya}

Majelis Taklim Khoirun Nisa' merupakan perkumpulan pengajian ibu-ibu yang berada di Wonokusumo Kidul, Kelurahan Pegirian, Kecamatan Semampir, Surabaya Utara. Sebelum berdirinya majelis taklim ini, di Wonokusumo Kidul pernah ada pengajian mingguan ibu-ibu yang biasanya dilaksanakan tiap hari Kamis malam Jumat. Akan tetapi sejak terjadinya kebakaran di kampung Wonokusumo Kidul pada tahun 2009 yang mengakibatkan rumah-rumah warga terbakar dan banyak yang pindah, menyebabkan jumlah anggota pengajian ibu-ibu tersebut menurun drastis dan akhirnya berhenti. ${ }^{35}$ Pada tahun 2015 munculah keinginan dari ibu-ibu untuk mengadakan perkumpulan pengajian ibuibu lagi. Salah satunya seperti apa yang disampaikan oleh Ibu Kh, "Kulo ancene kepikiran mas, mosok kampung iki gak onok

35 Ibu K, Wawancara oleh Penulis, 24 September 2018. pengajiane, nang endi-endi yo kampung mesti onok pengajian ibu-ibu e. nek kampung gak onok pengajiane lak yok opo, dadine kan sepi, trus gak onok berkahe. Akhire kulo cobak menghubungi mbak $K$ terus mak $Y$, awale mak $Y$ ambek mbak $K$ rodok abot, tapi cobak terus, akhire bu $K$ purun ngawali, akhire dimulai niku sekitar tahun 2015 akhir pengajiane. (Saya memang kepikiran mas, masak kampung ini tidak ada pengajiannya, dimana-manapun pasti ada pengajian ibu-ibunya. Kalau kampung tidak ada pengajiannya jadinya sepi dan tidak ada berkahnya. Akhirnya saya coba menghubungi mbak $K$ dan mak $Y$, awalnya mak $Y$ dan mbak $K$ agak keberatan, tapi coba terus, akhirnya bu $K$ mau mengawali, akhirnya pengajian ibu-ibu diawali sekitar akhir tahun 2015)."136

Adanya desakan dari beberapa orang kepada Ketua Majelis Taklim Khoirun Nisa' untuk mendirikan lagi pengajian ibu-ibu, dan

\footnotetext{
36 Ibu Kh, Wawancara oleh Penulis, 24 September 2018.
} 
adanya semangat ingin merubah kampung agar lebih baik, membuat Ketua Majelis Taklim Khoirun Nisa' akhirnya mau untuk membulatkan tekad mendirikannya. Hal ini seperti yang dituturkan oleh Ketua Majelis Taklim, "Daerah kene memange ket biyen terkenal daerah sing rusak mas, onok sing bandar Narkoba digrebek polisi, judi iku wes biasa sampek pernah digrebek bolak balik, ngombe-ngombe tiap onok mantenan melekan iku biasa, biasane ngombe-ngombe ambek judi, sampek onok sing gara-gara utang mateni tonggone dhewe, nau'dzubillah min dzaalik.... Kulo pengene kampung mriki gak tambah rusak, mangkane kulo ngedekno pengajian ibu-ibu, sebab ibu-ibu kan sing nentukno akhlake anake, apik eleke anak tergantung teko ibuke. (Daerah sini adalah daerah yang rusak, ada yang jadi bandar Narkoba sampai digrebek Polisi, judi itu sudah ditangkap berkali-kali, tiap ada yang punya hajatan biasanya ada minum-minuman sama judinya, bahkan ada yang sampai gara-gara hutang membunuh tetangga sendiri, nau'dzubillah min dzaalik... Saya tidak ingin kampung ini menjadi semakin rusak, makanya saya ingin mendirikan pengajian ibu-ibu, karena ibu-ibu itulah yang menentukan akhlak anaknya, baik buruknya akhlak anaknya tergantung ibunya)."37

Selanjutnya Ketua Majelis Taklim Khoirun Nisa' yang juga mengelola TPA Baitul Ilmi, mengkoordinasi orang tua murid-muridnya untuk mengadakan pengajian ibu-ibu yang kemudian terkumpul beberapa orang, kemudian dimulailah pengajian, saat itu pengajian diawali di rumah Ibu M. ${ }^{38}$ Dengan

\footnotetext{
37 Ibu K, Wawancara, 24 September 2018.

38 Ibid.

39 Ibid.

40 lbu K \& Ibu Kh, Wawancara.
}

diawalinya pengajian tersebut, menjadi momentum awal berdirinya pengajian ibuibu. Setelah itu selang beberapa bulan, saat pengajian di Balai RW-06, pengajian tersebut diberi nama Majelis Taklim Khoirun Nisa' dan diresmikan serta dipimpin doanya oleh Bu Nyai Hj. DR. dr. Siti Nur Asiyah, M.Ag. ${ }^{39}$

Berdasarkan pernyataan dari Ibu Kh dan Ketua Majelis Taklim Khoirun Nisa', pada awalnya yang ikut pengajian ini, jumlahnya delapan belas orang. Kemudian berkembang menjadi tiga puluh, dan berkembang lagi sampai menjadi lima puluhan orang. Beberapa ada yang keluar atau tidak aktif sehingga sampai bulan September 2018, anggota pengajian sekitar tiga puluh delapan orang. ${ }^{40}$

Secara visi misi organisasi, sebagaimana yang disampaikan oleh ketua Majelis Taklim Khoirun Nisa', bahwa harapan ibu-ibu dengan berdirinya pengajian Majelis Taklim Khirun Nisa' dapat menjadi wadah ibu-ibu muslimah Wonokusumo Kidul untuk bersilaturrahmi dan mengaji. ${ }^{41}$ Selain mengaji, ternyata pengajian ibu-ibu Majelis Taklim Khoirun Nisa' juga mempunyai manfaat buat warga. Hal ini seperti yang disampaikan oleh pak A selaku ketua RW-06, bahwa dengan adanya Majelis Taklim Khoirun Nisa' memberikan pengaruh ke warga, khususnya ketika ada warga yang ingin kirim doa atau punya hajat, akan tetapi hal ini kebanyakan yang merasakan adalah ibu-ibu yang sudah usia lanjut, ibu-ibu muda belum banyak merasakannya. ${ }^{42}$ Selain itu dengan adanya pengajian ini, bisa

\footnotetext{
41 Ibu K, Wawancara.

42 Pak A (Ketua RW-06), Wawancara oleh Penulis, 27 September 2018.
} 
meningkatkan kerukunan antar warga, berkumpul bersama tiap minggu dan berbincang-bincang. Mungkin biasanya antar warga sibuk dengan pekerjaan dan urusan keluarga masing-masing, dengan adanya pengajian ibu-ibu ini bisa ada waktu untuk bertemu dengan sesama warga dan saling menjalin hubungan yang baik. ${ }^{43}$

Kegiatan yang dilakukan oleh Majelis Taklim Khoirun Nisa' antara lain pengajian rutin mingguan. Awalnya tiap Rabu malam Kamis, karena ada masukan dari beberapa anggota akhirnya waktunya diubah menjadi hari Kamis malam Jumat, di dalamnya diisi dengan mengaji yasin, tahlil dan terkadang ada ceramah agama juga. Ceramah agama kadang diisi oleh pengisi atau bu Nyai dari luar, dan yang sering diisi oleh pengisi dari dalam atau dari anggota pengajian sendiri. Selain itu, ada juga program pengajian yang tidak rutin, misalnya ada salah satu anggota yang hajatan memperingati seratus hari meninggalnya anggota keluarga, pengajian persiapan berangkat umroh, ulang tahun anak, dan lain-lain. ${ }^{44}$ Program yang lain adalah program sosial, seperti menjenguk jika ada anggota atau keluarga inti anggota jamaah yang sakit juga membantunya dengan dana yang diambil dari uang kas pengajian. Kalau ada anggota atau keluarga anggota jemaah yang meninggal, maka akan ada takziyah dari anggota lainnya, kemudian melakukan pengajian yasin dan tahlil di rumah duka, dan pemberian santunan dari uang kas pengajian. Program yang lainnya adalah pengadaan uang kas. Tiap anggota membayar uang kas sebesar lima ribu rupiah. Uang tersebut diberikan kepada giliran jemaah yang rumahnya ditempati untuk pengajian. Selanjutnya ada program

43 Ibid.; Ibu R dan Ibu Re, Wawancara oleh Penulis.

${ }^{44}$ Ibu K, Wawancara. pengadaan pengeras suara, karena setiap ada pengajian membutuhkan pengeras suara (sound system), kadang berbarengan dengan kegiatan tahlilan bapak-bapak. Yang terakhir adalah program pengadaan baju seragam pengajian, setiap anggota diberi baju seragam yang dananya diambilkan dari kas pengajian Majelis Taklim Khoirun Nisa'. ${ }^{45}$

Karena masih baru dan kegiatannya tidak membutuhkan struktur organisasi yang rumit, maka Majelis Taklim Khoirun Nisa' hanya membuat struktur organisasi inti saja, yang terdiri dari ketua, wakil ketua, sekretaris, dan bendahara. Pengurus yang menduduki struktur itu antara lain, Ketua pengajian Ibu K, Wakil Ketua Ibu Kh, Sekretaris Ibu E, dan Bendahara Ibu T.

\section{Kepemimpinan pada Majelis Taklim Khoirun Nisa' yang Berbasis Kecerdasan Emosi}

1. Kecerdasan Emosi Pemimpin saat Pendirian Majelis Taklim Khoirun Nisa'

Saat masa awal mendirikan organisasi Majelis Taklim Khoirun Nisa', kecerdasan emosi pemimpin terlihat ketika mencoba memahami keadaan masyarakat serta kebutuhan masyarakat. Kebutuhan masyarakat terhadap adanya pengajian ibuibu, beliau memahami harapan orang-orang kampung yang mempersepsi harusnya memang setiap kampung ada pengajian ibuibunya, sebab kalau kampung tidak ada pengajiannya khususnya pengajian ibu-ibu maka kampung akan menjadi sepi dan bagi orang kampung jika di dalam kampung tidak ada pengajiannyanya terutama pengajian ibu-ibunya, maka mereka merasakan akan

\footnotetext{
45 Ibu Kh, Wawancara.
} 
berdampak tidak ada keberkahan di dalam kampung itu. Kebutuhan tersebut sebagaimana yang disampaikan oleh Ibu Kh dalam wawancara, yang menyatakan bahwa beliau merasa resah apabila di kampungnya tidak ada kelompok pengajian ibu-ibu, dan khawatir apabila kampungnya tidak berkah. ${ }^{46}$

Dari pernyataan di atas, menunjukkan bahwa masyarakat membutuhkan adanya pengajian, dan akhirnya Ibu Kh berusaha meminta agar ada yang mau memimpin dan dari dua orang yang Ibu Kh minta, ternyata Ketua pengajian Majelis Taklim Khoirun Nisa' saat itulah yang memahami kebutuhan itu dan mau untuk memimpin dan mendirikan pengajian ibu-ibu yang lama berhenti. Hal ini membuktikan bahwa Ketua Majelis Taklim Khoirun Nisa' mempunyai kecerdasan emosional dalam aspek kemampuan kesadaran sosial (social awareness), yakni mampu merasakan apa yang dirasakan atau dibutuhkan oleh lingkungannya.

Kemampuan kesadaran sosial (social awareness) ini diperkuat dengan pernyataan dari Ketua Majelis Taklim Khoirun Nisa'. Beliau menjelaskan bahwa, wilayah kampungnya adalah daerah yang rusak. Dalam arti banyak perilaku negatif dari masyarakatnya, seperti judi, minuman keras, narkoba, bahkan sampai konflik antartetangga yang berujung pembunuhan. Beliau menyatakan tidak ingin kampungnya menjadi semakin rusak. Caranya adalah dengan menghidupkan kelompok pengajian ibu-ibu, karena menurutnya ibu adalah yang menentukan akhlak anak-anaknya. ${ }^{47}$
Dari penjelasan di atas, menunjukkan bahwa kesadaran Ketua akan kondisi sosial masyarakat (social awareness) sangatlah tinggi. Pemahaman akan realitas masalah yang terjadi disekitarnya dan empatinya terhadap masalah tersebut. Hal itulah yang menggugah subjek untuk andil dalam memperbaiki keadaan lingkungannya dan tidak malah membiarkannya.

Dengan kesadaran sosialnya Ketua Majelis Taklim Khoirun Nisa' mempunyai semangat untuk mendirikan pengajian. Namun, untuk mendirikan pengajian tidaklah mudah, subjek harus bergelut dengan perasaan dirinya. Di sinilah terlihat bagaimana kemampuan kesadaran diri (self awareness) dari subjek. Sebenarnya di awal-awal, saat subjek menerima masukan dari beberapa ibu-ibu kampung untuk mendirikan pengajian ibu-ibu masih mengalami keraguan. Hal tersebut terlihat dari pernyataannya, "...awalnya saya ragu, engkok nek gak onok sing gelem melu yok opo? Nek akeh sing nolak yok opo? (.... awalnya saya ragu, nanti kalau tidak ada yang mau ikutbagaimana? kalau banyak yang menolak bagaimana?)." Keraguan ini sebenarnya sesuatu yang wajar, sebab pengajian ibu-ibu sudah tidak aktif sejak lama sekitar lima tahun lebih. Sampai kemudian beliau mencoba untuk menguatkan dirinya, mengatasi masalah emosi dirinya dan membangun tekad dan keberanian untuk mendirikan pengajian ibuibu, beliau menyatakan, "Saya ngumpulkan ibu-ibu awalnya dari wali murid santri-santri saya di TPA Baitul IImi, saya ajak mereka yang mau untuk ngaji, yang tidak mau tidak apa-apa, tidak memaksa, sebab yang butuh ngaji sebenarnya kita sendiri, dan

\footnotetext{
47 Ibu K, Wawancara.
} 
alkhamdulillah ibu-ibu wali murid mau hadir, dan saya kaget ternyata ada ibu-ibu lainnya yang mau ikut juga." 48

Dari data di atas, dapat diketahui bagaimana kecerdasan emosional Ketua Majelis Taklim Khoriun Nisa' khususnya dalam aspek kemampuan memahami kondisi diri (self awareness) dan kemampuan dalam pengelolaan emosi dirinya (emosional management). Kemampuan memahami kondisi (self awareness) diketahui dengan kemampuan menyadari emosi-emosi yang berada dalam dirinya saat mendapat masukan dari beberapa ibu-ibu kampung. Menyadari bahwa dia sedang dalam keadaan ragu, khawatir kalau yang datang sedikit, khawatir kalau banyak yang menolak ide pendirian pengajian ibu-ibu. Kesadaran diri inilah yang kemudian menjadi pijakannya dalam mengendalikan emosi khawatir yang ada dalam dirinya (self management). Subjek berusaha meyakinkan dirinya dengan nilai-nilai yang ada, bahwa yang membutuhkan pengajian adalah setiap orang, karena setiap orang butuh bekal untuk akherat. Akhirnya dari situ timbulah keyakinan bahwa ide pengajian ibu-ibu, pasti ada yang mendukung walaupun tidak banyak. Subjek sedari awal tidak memasang target harus banyak orang yang datang, dan berusaha untuk ikhlas, menerima berapapun yang ikut. Subjek juga tidak memaksa ibu-ibu untuk ikut, dan ternyata di luar perkiraan, yang ikut (awal) lebih banyak, sekitar delapan belas orang. Kemampuan seperti ini menggambarkan bagaimana kecerdasan emosional khususnya dalam aspek kemampuan manajemen emosi diri (self management) Ketua Majelis Taklim Khoirun Nisa'.
Selain kemampuan kecerdasan emosi berupa kesadaran diri (self awareness), pengelolaan emosi diri (self management), dan kesadaran sosial (social awareness), Ketua Majelis Taklim Khoirun Nisa' dalam proses pendirian pengajian ibu-ibu, menunjukkan kecerdasan emosionalnya dalam bentuk kemampuan membangun relasi (relationship management). Hal ini terlihat dalam pernyatan subjek di atas, bahwa pertama kali mendirikan pengajian ibu-ibu, subjek mengajak ibu-ibu yang kebanyakan adalah ibu-ibu wali santri dari TPA Baitul Ilmi juga beberapa tetangganya. Ibu-ibu tersebut tentunya mau diajak oleh subjek sebab adanya hubungan atau relasi sosial yang terbangun dengan baik sejak sebelumnya. Apabila ibu-ibu wali murid santri TPA Baitul IImi dan ibu-ibu tetangganya sudah ada perasaan tidak enak, benci, atau dendam dengan ketua Majelis Taklim Khoirun Nisa' maka akan sulit bagi ibu-ibu tersebut untuk mengikuti pengajian. Kemampuan menjalin relasi yang baik ini, juga diperkuat dengan data bahwa yang hadir di awal pembukaan pengajian di luar ekspektasi, meskipun proses mengajaknya secara sederhana saja. Hal tersebut mengindikasikan adanya hubungan sosial yang positif sebelumnya.

\section{Kecerdasan Emosi Pemimpin saat} Menjalankan Program Majelis Taklim Khoirun Nisa'

Setelah organisasi didirikan, maka organisasi perlu dijalankan. Agar dapat berjalan dengan baik, maka butuh arahan-arahan dari pemimpin agar program yang disepakati bersama bisa terwujud, namun

$48 \mathrm{lbid}$. 
dalam menjalankan organisasi, tentunya tidak lepas dari dinamika. Dari seluruh proses dinamika yang dijalankan oleh Ketua Majelis Taklim Khoirun Nisa' dalam memimpin organisasi, dapat digambarkan kecerdasan emosional yang dimiliki oleh beliau dalam memimpin.

Pertama, saat menjalankan program pengajian rutin. Ketua dalam tausiyah (nasehatnya) sering menyampaikan kepada anggota pengajian ibu-ibu agar dalam memberikan konsumsi tidak perlu dipaksakan harus berupa makanan, tidak harus makanan besar, namun disesuaikan dengan kondisi masing-masing sehingga tidak perlu dipaksakan. Sebab jika dipaksakan sampai berlebihan, kemudian ketika kurang, jadinya hutang ke sana kemari. Jika seperti itu maka dampak buruknya akan lebih besar daripada manfaatnya. Hal ini seperti yang beliau sampaikan, "...kulo nggeh nyampekno ten jamaah, konsumsine gak kudhu ngekei mangan, cukup jajan wae mboten noponopo, ojok sampek meksakno, sing penting iku ngajine lan keberkahane, daripada dipaksakno, terus ngutang kono-kene tambah akeh mudhorote daripada manfaate." (Saya juga menyampaikan ke jamaah, konsumsinya tidak harus makan, cukup makanan kecil saja tidak apa-apa, jangan sampai memaksakan, yang terpenting itu kita mengaji dan keberkahannya, daripada dipaksakan kemudian berhutang kesana-kemari tambah banyak keburukannya daripada kebaikannya)." ${ }^{\prime 49}$

Dari data tersebut menunjukkan bahwa Ketua Majelis Taklim Khoirun Nisa' mempunyai kesadaran sosial (social awareness) terkait rasa empatinya terhadap keadaan ibu-ibu yang ikut pengajian. Walaupaun ibu-ibu yang giliran rumahnya ditempati pelaksanaan pengajian mendapatkan uang konsumsi dari kas, akan tetapi kalau dipaksakan harus menyediakan makanan berat (nasi soto/nasi tumpeng, dan sebagainya), ditambah jajan dan makanan kecil, bisa jadi uang konsumsi yang diberikan tidak mencukupi. Padahal secara kondisi ekonomi jemaahnya banyak yang menengah ke bawah. Kalau yang ekonominya berkecukupan mungkin tidak masalah, akan tetapi bagi yang ekonominya ke bawah, kekurangan dalam menyediakan konsumsi ini, akan mengakibatkan mereka kemudian berhutang. Hal tersebut dampak negatifnya juga besar, bisa menambah beban ekonomi keluarga ibu-ibu yang ikut pengajian. Beban ekonominya yang bertambah akan berdampak pada keharmonisan rumah tangga, sebab karena hutang bisa membuat pertengkaran keluarga bahkan antar anggota keluarga. Kondisi seperti ini, sangat dipahami oleh Ketua Majelis Taklim Khoirun Nisa', oleh karena itu beliau sering menyampaikan nasehat agar tidak berlebih-lebihan dalam memberikan konsumsi, secukupnya saja, yang terpenting itu mengajinya dan keberkahannya. Selain itu, dari data tersebut menunjukkan kemampuan kecerdasan emosi Ketua Majelis Taklim Koirun Nisa' terutama dalam hal mengelola relasi dengan baik (relationship management). Sebab dengan empati akan membuat anggota pengajian ibu-ibu merasakan adanya perhatian dari pemimpin, dan empati ini akan berdampak pada relasi sosial yang terbangun semakin

\footnotetext{
49 Ibid.
} 
baik antara subjek sebagai pemimpin dengan anggota yang dipimpinnya.

Kedua, kecerdasan emosi pemimpin Majelis Taklim Khoirun Nisa' saat ada persoalan anggota yang menggunjing masalah makanan yang disajikan waktu pengajian. Anggota ada yang membandingbandingkan, ada yang menyatakan sajian makanannya si " $A$ " dan si "B" tidak enak. Saat mendengar hal tersebut, Ketua awalnya mau marah sebab masalah makanan saja kenapa dipermasalahkan, akan tetapi subjek kemudian mencoba untuk meredam kemarahannya tersebut. Subjek menyadari kalau sampai kemarahan ini langsung diluapkan akan berdampak tidak baik. Subjek mencoba memahami sebab permasalahn tersebut, yang diindikasi karena beberapa anggota belum menghayati tujuan dari pengajian, dan dampak sosial dari menggunjing. Dalam momentum setelah pengajian, Ketua menyampaikan kepada anggotanya tentang tujuan dari pengajian, bahwa tujuan pengajian adalah lillaahita'ala, niat mengaji dan mencari ilmu, berharap pahala dari Allah, bukan berharap mendapatkan makanan yang enak, sehingga mendapatkan makanan apapun, diterima dengan ikhlas sebagai berkah dari Allah. Tidak perlu digunjingkan karena akan menyinggung perasaan orang lain, yang bisa mengakibatkan permusuhan, prasangka yang tidak baik, dan akhirnya keluar dari pengajian karena masalah makanan. Jangan sampai hal yang awalnya baik, malah menjadi buruk.

Dari peristiwa di atas dapat diketahui bagaimana kemampuan self awareness Ketua Majelis Taklim Khoirun Nisa' dalam membaca keadaan emosi diri saat mendengar orang yang menggunjingkan masalah sajian makanan saat pengajian. Subjek menyadari bahwa dirinya dalam keadaan marah, akan tetapi mencoba mengendalikan dirinya. Kemampuan self management ini terlihat saat subjek sebagai pemimpin mencoba mengendalikan emosi marahnya dengan manghayati dampak kalau kemarahannya diluapkan justru tidak baik, selanjutnya subjek mencoba mendalami sebab orang-orang menggunjing masalah makanan sampai menemukan akar masalahnya. Kemampuan social awareness terlihat dari kepedulian subjek sebagai pemimpin untuk memecahkan masalah ini dengan mencoba memberikan masukan terhadap anggota pengajian Majelis Taklim Khoirun Nisa' akan tujuan pengajian yang sebenarnya dan memberikan penyadaran dampak negatif menggunjing. Sedangkan kemampuan relationship management terlihat dari kemampuan subjek sebagai seorang pemimpin dalam memecahkan masalah tersebut, sehingga potensi konflik sosial yang bisa muncul dapat teratasi dan pengajian dapat berjalan dengan lancar.

Ketiga, salah satu bentuk kecerdasan emosi pemimpin Majelis Taklim Khoirun Nisa' juga bisa dilihat dalam insiasi programnya, yaitu program mendoakan dan memberikan bantuan kepada anggota yang kesusahan. Dalam wawancara, seperti yang disampaikan oleh Ketua RW. 06 bahwa pengajian ibu-ibu Majelis Taklim Khoirun Nisa' juga mempunyai manfaat buat warga. Dengan adanya pengajian tersebut memberikan bagi ketenangan dan ketenteraman warga, khususnya ketika ada warga yang ingin kirim doa atau punya 
hajat. $^{50}$ Lebih detailnya, Ibu Kh juga menyampaikan bahwa salah satu program kegiatan Majelis Taklim Khoirun Nisa' adalah program sosial, seperti menjenguk jika ada anggota atau keluarga inti anggota jemaah yang sakit juga membantunya dengan dana yang diambil dari uang kas pengajian. Kalau ada anggota atau keluarga anggota jamaah yang meninggal, maka akan ditakziyahi dan diadakan pengajian yasin dan tahlil bersama di rumah duka, juga diberikan santunan dari uang kas pengajian." ${ }^{51}$ Dalam program ini, subjek menjelaskan bahwa ketika ada anggota yang sakit atau keluarganya sakit, atau ada keluarga anggotanya yang meninggal, Ketua turut serta memintakan dan memimpin doa yang dikhususkan kepada anggota yang sedang mengalami kesusahan. Selain itu, subjek juga memberikan teladan dan mengajak anggota lainnya untuk menjenguk anggota yang sakit.

Adanya program tersebut, serta keteladanan dari pimpinan dalam pelaksanaannya, menunjukkan bagaimana aspek kesadaran sosial (social awareness) dan pengelolaan relasi (relationship management) yang dimiliki oleh subjek. Aspek kesadaran sosial (social awareness) dapat dilihat dari Ketua Majelis Taklim Khoirun Nisa' yang ikut merasakan apa yang dirasakan oleh anggotanya ketika mendapatkan musibah, baik berupa sakit ataupun meninggal dunia. Dalam keadaan tersebut, Ketua Majelis Taklim Khoirun Nisa' memahami bahwa yang dibutuhkan oleh seorang muslim yang sedang kesusahan adalah doa, perhatian dan dukungan baik secara material dan spiritual. Oleh karena itu, dengan memahami kondisi perasaan

\footnotetext{
50 Pak A (Ketua RW-06), Wawancara.

51 Ibu Kh, Wawancara.
}

anggota yang sedang dalam kesedihan tersebut, maka Ketua Majelis Taklim Khoirun Nisa' mendukung bahkan menjadi yang terdepan dalam melaksanakan program mendoakan angggota yang sedang kesusahan dan memberikan bantuan. Dengan adanya empati yang diwujudkan secara nyata dalam bentuk dukungan doa, perhatian dengan didatangi dan bantuan material, maka dapat menguatkan hubungan sosial yang terjalin antara ketua Majelis Taklim Khoirun Nisa. Kemampuan menjalin hubungan sebagaimana di atas menjelaskan bagaiamana kecerdasan sosial dalam aspek pengelolaan hubungan sosial (relationship management) yang dimiliki oleh subjek.

Keempat, selain program rutin pengajian dan program sosial, pada akhir tahun 2017 anggota pengajian mengusulkan kepada ketua untuk mengadakan program tambahan, yaitu program pengadaan seragam pengajian dan program pembelian sound system serta tikar. Namun karena sound dan tikar masih ada yaitu dengan meminjam inventaris RW, maka banyak yang mengusulkan uang kas agar digunakan untuk pembelian seragam pengajian. Saat proses penentuan program tersebut, ada salah seorang anggota yang tidak setuju yang kemudian keluar. Ketika ada yang keluar, Ketua Majelis Taklim Khairun Nisa' menyampaikan, "... kan, lebih banyak yang menginginkan baju seragam, sebab kalau sound dan tikar masih ada, sehingga ketika ada yang tidak sepakat satu orang, ya saya kasih pengertian, ketika orangnya masih tidak mau, ya bagaimana lagi, masak keputusan bersama dikalahkan sama satu orang ?"52 Ketika orang tersebut mau keluar,

52 Ibu K, Wawancara. 
ketua Majelis Taklim Khoirun Nisa' mengajaknya berkomunikasi, "Lapo nak, kok metu, gak eman ta? (Kenapa nak, kok keluar, apa tidak sayang?)" Anggota tersebut menyampaikan ke Ketua Majelis Taklim ketika mau keluar, "...memange melu pengajian iki wajib ta buk? (... memangnya ikut pengajian ini wajib ta bu?)." Lalu dijawab oleh Ketua Majelis Taklim Khoirun Nisa', "Nek melu pengajian iki ancene gak wajib, tapi nek ngaji, nuntut ilmu iku yo wajib (Kalau ikut pengajian ini tidak wajib, tapi kalau mengaji, mencari ilmu wajib)." Bahkan dalam salah satu penyampaiannya subjek agak marah, sebab ada beberapa pernyataan dari anggota tersebut dirasa agak menyudutkan, subjekpun kemudian menyampaikan, "... yok opo-yok opo wong mati butuh wong liyo, butuh didungakno nduk!" (... bagaimanapun juga, orang meninggal juga membutuhkan orang lain, membutuhkan doa orang lain, nak!). ${ }^{53}$ Akhirnya program pembelian seragam pengajian terlaksana dengan konsekuensi salah satu anggota tidak aktif dan itu disadari oleh Ketua Majelis Taklim Khoirun Nisa' sebagai risiko.

Dari peristiwa di atas, menunjukkan bahwa ketika Ketua Majelis Taklim Khoirun Nisa' menetapkan suatu program, subjek mencoba memahami terlebih dahulu apa yang menjadi keinginan-keinginan dan harapan dari anggota Majelis Taklim Khoirun Nisa'. Setelah memahami keinginankeinginan tersebut, subjek kemudian mencoba merumuskannya dalam bentuk pilihan kebijakan. Namun subjek tidak langsung memutuskan, beliau musyawarahkan dulu dengan anggota. Ketika terjadi perbedaan pendapat, ada yang menginginkan uang kas dibuat membeli sound system dan ada yang menginginkan dibelikan seragam, maka kemudian dilakukan pemilihan suara terbanyak. Ketika ternyata banyak yang memilih membeli seragam pengajian, maka hal tersebut disepakati, walaupun risikonya ada salah satu anggota yang tetap tidak setuju dan memilih keluar. Menyikapi hal tersebut, subjek tidak langsung membiarkan begitu saja, namun mencoba untuk mengajak berkomunikasi. Tetapi ketika yang bersangkutan tetap ingin keluar, maka subjek tidak memaksakannya, dan memberinya nasehat walaupun dengan nada menahan emosi kemarahan karena pertanyaan yang menyudutkan.

Fenomena penentuan program pengadaan seragam pengajian di atas menunjukkan bagaimana aspek kemampuan memahami diri (self awareness), pengendalian diri (self management), kesadaran sosial (social awareness), maupun pengelolaan hubungan relasi (relationship management) yang ada pada Ketua Majelis Taklim Khoirun Nisa'. Kemampuan memahami diri (self awareness) dan kemampuan pengendalian diri (self management) ditunjukkan dengan kemampuannya dalam memahami perasaannya sendiri, yaitu saat mendapatkan pernyataan dari salah seorang anggota yang menyinggung perasaannya, subjek merasakan marah dan menyadari hal itu. Oleh karena itu subjek mencoba mengendalikan diri agar ucapan yang keluar tidak sampai berupa kata-kata kotor atau kata-kata kasar yang menyakitkan hati. Dari data di atas terlihat bahwa dalam penyikapannya, kata-kata disampaikan adalah bahwa kalau ikut pengajian ini

$53 \mathrm{lbid}$. 
memang tidak wajib, tapi kalau mengaji, mencari ilmu wajib), menunjukkan bahwa beliau masih bisa berpikir rasional dan menjawab dengan tepat pertanyaan menyudutkan dari salah satu. Selanjutnya sekalipun subjek marah karena ada pernyatan-pernyataan yang menyudutkan, namun tetap bisa mengendalikannya. Subjek menyikapi hal tersebut dengan katakata yang masih berisi nasehat yang mengingatkan akan kematian, bahwa orang yang mati sekalipun butuh doa orang lain, kalimat tersebut jauh dari kata-kata kotor dan kalimat yang menyakitkan.

Dari aspek relasi sekalipun ada anggota yang keluar, akan tetapi secara keseluruhan, Ketua Majelis Taklim Khoirun Nisa' berani mengambil keputusan yang itu memberikann dampak positif terhadap pengelolaan relasi yang lebih besar. Sedangkan kemampuan kesadaran sosialnya (social awareness), terlihat dari bagaimana Ketua Majelis Taklim Khoirun Nisa' dalam memahami kebutuhan dari anggotanya, subjek tidak langsung memutuskan secara sepihak apa yang menjadi keinginannya, tapi subjek mau mendengarkan masukanmasukan dari anggotanya, sehingga dapat memahami apa yang menjadi kebutuhan atau harapan dari anggotanya.

\section{Kesimpulan}

Studi ini menggambarkan bagaimana Ketua Majelis Taklim Khoirun Nisa' menerapkan kepemimpinan berdasarkan kecerdasan emosi. Hal tersebut dapat dilihat dari kemampuan kesadaran diri (self awareness) yang dibuktikan dengan kesadaran emosi yang menyertainya saat mendirikan pengajian ibu-ibu, saat menyadari emosi diri waktu mendapatkan pernyataan yang menyudutkan dari anggota pengajian, dan saat menyadari emosi marah sewaktu ada anggota yang menggunjing masalah makanan. Kemampuan pengendalian diri (self management) diindikasikan dengan kemampuan mengendalikan emosi kekhawatirannya saat mendirikan pengajian, kemampuan mengendalikan emosi marah saat mendapatkan pernyataan yang menyudutkan dari anggota, dan saat mendengar ada anggota yang menggunjing masalah makanan. Kesadaran sosial (social awareness) dan kemampuan pengelolaan relasi (relationship management) yang diindikasikan oleh subjek ketika mendirikan Majelis Taklim Khoirun Nisa', memberikan nasehat tentang konsumsi pengajian, memimpin program doa dan memberi bantuan untuk anggota yang kesusahan, dan pengadaan seragam pengajian.

Terdapat beberapa temuan yang menjadi kekhasan dalam kepemimpinan berdasarkan kecerdasan emosi yang dimiliki oleh Ketua Majelis Taklim Khoirun Nisa'. Hal tersebut dapat menjadi inspirasi bagi para pemimpin organisasi pengajian khususnya pengajian ibu-ibu, yaitu: (1) kemampuan pengendalian diri (self management) adalah hal yang perlu dimiliki oleh ketua pengajian, khususnya pengajian ibu-ibu, sebab dengan pengendalian diri terutama saat mendapatkan stimulus yang membuat emosi marah, akan memberikan manfaat besar bagi berlangsungnya organisasi, sehingga ketika terjadi konflik, dapat diselesaikan dengan baik; (2) kesadaran sosial (social awareness) menjadi salah satu pendorong terpenting Ketua Majelis Taklim Khoirun Nisa' untuk mendirikan dan memimpin kelompok pengajian sampai kemudian berkembang. Tanpa adanya kesadaran sosial, maka sulit bagi ibu-ibu 
untuk mau berkorban mengelola pengajian. Sebab mengelola kelompok pengajian ibuibu tidak mendapatkan gaji atau uang. Demikian pula saat menyelesaikan masalah dalam menjalankan organisasi, perlu kepedulian yang tinggi dari seorang pemimpin; (3) dalam pengelolaan hubungan sosial (relationship management) tidak selalu ideal seperti yang diharapkan, akan tetapi ada saatnya dihadapkan pada situasi yang cukup sulit, terutama saat terjadi konflik antar anggota organisasi. Ketika hubungan relasi sosial dihadapkan pada konflik atau perbedaan pandangan, Ketua Majelis Taklim Khoirun Nisa' dapat memilih pilihan yang mampu mempertahankan relasi sosial yang lebih besar walaupun dengan konsekuensi hubungan sosial dengan salah satu anggota tidak baik.

\section{Bibliografi}

Daulay, Maslina. "Kepemimpinan dalam Manajemen Dakwah." Jurnal Hikmah, Vol. VI, 48 No. 02 (Juli 2012).

Detiknes.com "Pelaku Pembunuhan di TPI Romo Kalisari Tertangkap," detiknes.com, diunduh pada tanggal 19 Mei 2016, http//www.detiknews.com.

Goleman, Daniel., et al. Primal Leadership Kepemimpinan Berdasarkan Kecerdasan Emosi. Diterjemahkan Susi Purwoko. Jakarta: PT. Gramedia Pustaka Utama, 2006.

Harianto, Yudi Asmara. Kepemimpinan Rasulullah SAW pada Peristiwa Hudaibiyah Pendekatan Kepemimpinan Emotional Quotient (EQ). Jurnal Kajian \& Pengembangan Manajemen Dakwah, Vol. 05, No. 2, (Desember 2015).

Helstad, Kristin \& Moller, Jorunn. "Leadership as Relational Work: Risks and Opportunities", International Journal Leadership In Education, Vol. 16, No. 3 (2014).

Jayadina, Afnani. "Fungsi Sosial Pengajian Bergilir di Rumah Warga (Studi tentang Pengajian Bergilir dan Upaya Memakmurkan Masjid di Dusun Pugeran, Jambidan, Banguntapan, Bantul, Yogyakarta." Skripsi, Universitas Islam Negeri Sunan Kalijaga, Yogyakarta, 2016.

Karyanto, Rizki. "Primal Leadership Khalifah Umar bin Abdul Aziz," Jurnal Kajian \& Pengembangan Manajemen Dakwah, Vol. 07, No. 01, (Juni 2017). . "Kepemimpinan Berbasis Kecerdasan Emosi (Studi Pada Komunitas Pelajar Tanpa Pacaran dan Remaja Masjid Ar-Rahman Surabaya)." Tesis, Universitas Islam Negeri Surabaya, 2018.

Lensalndonesia.com "Judi undangan Wonokusumo Digerebek Polisi," Lensalndonesia.com, diunduh pada tanggal 19 Mei 2016, http//www.Lensalndonesia.com.

Lunenburg, Fred C. "Emotional Intelligence in the Workplace: Application to Leadership", International Journal of Management, Business, And Administration.

Mahmuddin. "Kepemimpinan Dakwah." Jurnal Dakwah Tabligh, Vol. 15, No. 2, (Desember 2014).

Meirnayati Trihandini, R.A Fabiola. "Analisis Pengaruh Kecerdasan Intelektual, Kecerdasan Emosi, Dan Kecerdasan Spiritual Terhadap Kinerja Karyawan (Studi Kasus Pada Hotel Horison Semarang)." Tesis, Universitas Diponegoro, Semarang, 2005. 
Miftah, Thoha. Kepemimpinan dalam Manajemen: Suatu Pendekatan Perilaku, Cet. IV. Jakarta: Raja Grafindo Persada, 1993.

Moleong, Lexy J. Metodologi Penelitian Kualitatif: Edisi Revisi. Bandung: Remaja Rosdakarya, 2015.

Munir dan Ilahi, Wahyu. Manajemen Dakwah. Jakarta: Kencana, 2009.

Nawawi, Ismail. Metode Penelitian Kualitatif. Jakarta: Dwiputra Pustaka, 2012.

Nitisemito, Alex S. Manajemen: Suatu Dasar dan Pengantar. Jakarta: Ghalia Indonesia, 1989.

Pojokpitu.com "Polisi Tangkap 9 Penjudi di Makam Wonkid," pojokpitu.com, diunduh pada tanggal 19 Mei 2016, http//www.PojokPitu.com.

Safaria, Triantoro. Kepemimpinan. Yogyakarta: Graha Ilmu, 2004.

Sarifuddin, "Kepemimpinan Kepala Sekolah Berbasis Kecerdasan Emosional di SMA Negeri 1 Soppeng Riaja Kabupaten Barru." Tesis, IAIN Walisongo, 2010.

Siagian, Sondang P. Organisasi, Kepemimpinan dan Perilaku Administrasi. Jakarta: Gunung Agung, 1986.

Surabayanews.net. "Hutang 14 Juta Wanita Paruh Baya Dibunuh Dengan Sadis," Surabayanews.net, diunduh pada tanggal 19 Mei 2016, pukul 16:06 http//www.surabayanews.net.

Surya.co "Pejudi 'Tiarap', Pagupon Dibakar," Surya.co, diunduh pada tanggal 19 Mei 2016, http//www.surya.co.id.

Syamsi, Ibnu. Pengambilan Keputusan dan Sistem Informasi. Jakarta: Bumi Aksara, 1995.

Veithzal Rivai \& Arviyan Arifin. Islamic Leadership: Membangun Superleadership Melalui Kecerdasan Spiritual. Jakarta: Bumi Aksara, 2009.

Weisinger, Hendrie. Emotional Intelligence at Work, terj. Roro Ratih Ambarwati. Jakarta: Buana IImu Populer, 2006.

Yukl, Gary. Kepemimpinan Dalam Organisasi, terj. Budi Supriyanto. Jakarta: Indeks, 2005. 